\title{
Distribution of Sulfate-Reducing Bacteria in the Environment: Cryopreservation Techniques and Their Potential Storage Application
}

\author{
Ivan Kushkevych ${ }^{1, *} \mathbb{0}$, Aneta Kovářová ${ }^{1}$, Dani Dordevic ${ }^{2}{ }^{\circledR}$, Jonah Gaine ${ }^{3}$, Peter Kollar ${ }^{4} \oplus$, \\ Monika Vítězová ${ }^{1, * \mathbb{D}}$ and Simon K.-M. R. Rittmann ${ }^{5, * \mathbb{D}}$ \\ 1 Department of Experimental Biology, Faculty of Science, Masaryk University, Kamenice 753/5, \\ 62500 Brno, Czech Republic; 477109@mail.muni.cz \\ 2 Department of Plant Origin Food Sciences, Faculty of Veterinary Hygiene and Ecology, University of \\ Veterinary Sciences Brno, Palackého tř. 1946/1, 61242 Brno, Czech Republic; dordevicd@vfu.cz \\ 3 Department of Science, Technology Engineering and Mathematics, Faculty of Biological and Pharmaceutical \\ Sciences, Institute of Technology, Clash, Tralee, V92 CX88, Co. Kerry, Ireland; jonahgaine78@gmail.com \\ 4 Department of Pharmacology and Toxicology, Faculty of Pharmacy, Masaryk University, Palackého třída \\ 1946/1, 61200 Brno, Czech Republic; kollarp@pharm.muni.cz \\ 5 Department of Functional and Evolutionary Ecology, Archaea Physiology \& Biotechnology Group, \\ Universität Wien, 1090 Wien, Austria \\ * Correspondence: kushkevych@mail.muni.cz (I.K.); vitezova@sci.muni.cz (M.V.); \\ simon.rittmann@univie.ac.at (S.K.-M.R.R.); Tel.: +420-549-495-315 (I.K.); +431-427-776-513 (S.K.-M.R.R.)
}

check for

updates

Citation: Kushkevych, I.; Kovářová, A.; Dordevic, D.; Gaine, J.; Kollar, P.; Vítězová, M.; Rittmann, S.K.-M.R. Distribution of Sulfate-Reducing Bacteria in the Environment: Cryopreservation Techniques and Their Potential Storage Application. Processes 2021, 9, 1843. https:// doi.org/10.3390/pr9101843

Academic Editor: Antoni Sánchez

Received: 26 August 2021

Accepted: 13 October 2021

Published: 18 October 2021

Publisher's Note: MDPI stays neutral with regard to jurisdictional claims in published maps and institutional affiliations.

Copyright: (c) 2021 by the authors. Licensee MDPI, Basel, Switzerland. This article is an open access article distributed under the terms and conditions of the Creative Commons Attribution (CC BY) license (https:// creativecommons.org/licenses/by/ $4.0 /)$.
Abstract: Sulfate-reducing bacteria (SRB) are a heterogeneous group of anaerobic microorganisms that play an important role in producing hydrogen sulfide not only in the natural environment, but also in the gastrointestinal tract and oral cavity of animals and humans. The present review was written with the inclusion of 110 references including the time period from 1951 to 2021. The following databases were evaluated: Web of Science, Scopus and Google Scholar. The articles chosen to be included in the review were written mainly in the English and Czech languages. The molecular mechanisms of microbial cryoprotection differ depending on the environment where microorganisms were initially isolated. It was observed that the viability of microorganisms after cryopreservation is dependent on a number of factors, primarily colony age, amount of inoculum, cell size or rate of cooling, and their molecular inventory. Therefore, this paper is devoted to assessing the performance and suitability of various cryopreservation methods of intestinal bacteria, including molecular mechanisms of their protection. In order to successfully complete the cryopreservation process, selecting the correct laboratory equipment and cryopreservation methodology is important. Our analysis revealed that SRB should be stored in glass vials to help mitigate the corrosive nature of hydrogen sulfide, which can affect their physiology on a molecular level. Furthermore, it is recommended that their storage be performed in distilled water or in a suspension with a low salt concentration. From a molecular biological and bioengineering perspective, this contribution emphasizes the need to consider the potential impact associated with SRB in the medical, construction, and environmental sectors.

Keywords: anaerobic microorganisms; sulfate-reducing bacteria; hydrogen sulfide; toxicity

\section{Introduction}

Sulfate-reducing bacteria (SRB) are microorganisms that occur in different ecosystems globally [1-5]. They can also be isolated from the gastrointestinal tract and the oral cavity of humans and animals [6-11]. The cultivation of SRB is sometimes fastidious, as they require anaerobic conditions, strict temperature regulations and precise $\mathrm{pH}$ requirements [12]. Consequently, research on SRB is uncommon, and a method of long-term cryopreservation 
has not been thoroughly developed. Therefore, in this work we review methods for cryopreservation and their application for preservation of SRB $[13,14]$.

For cryopreservation, it is necessary to choose the right laboratory equipment in which long-term storage can be performed [15]. Another important step in cryopreservation is to select the right cryoprotectant to maximize the viability of the microorganism after freezing [13]. Although the type and concentration of the chosen cryoprotectant is critical, the possibility to combine different preservation compounds to achieve successful cryopreservation may be equally important. The viability of microorganisms is influenced by a number of factors [16]. Colony age, amount of inoculum, cell size or rate of cooling may impact the survival of the culture. Furthermore, viability can also vary between individual species within the same genus [13].

This review focuses on the following main points: SRB in various biotopes, conditions determining their viability, molecular aspects of cryopreservation, cultivation and storage, preservation of intestinal microbial communities and their viability and comparison of the obtained information with the possibility of application to SRB (Figure 1).

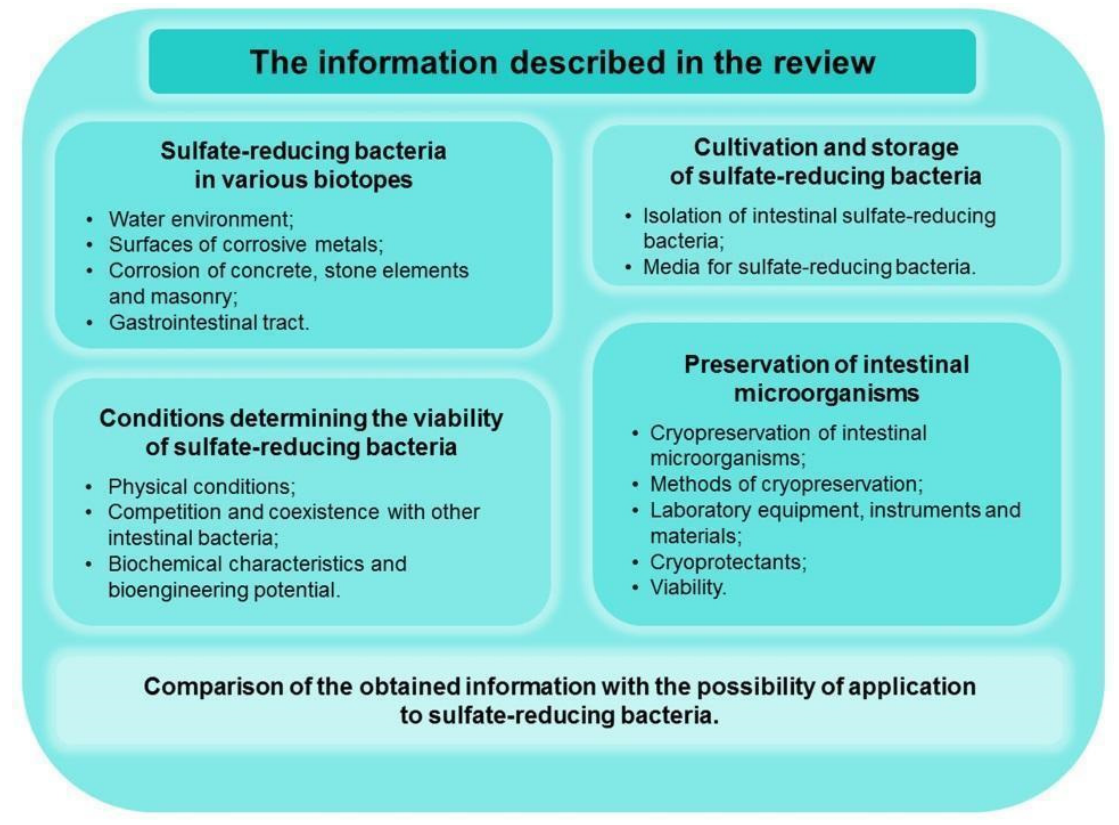

Figure 1. The scheme shows the information outlined in the review.

The aim of this systematic review was to describe the distribution of SRB in various environments, the individual steps related to the methods of cryopreservation of intestinal microorganisms and the subsequent comparison of the findings as to whether they are applicable to the long-term storage of SRB.

\section{Sulfate-Reducing Bacteria in Various Biotopes}

In terms of physiology, ecology and function, SRB can be isolated from various biotopes (water, mud, river sediment, sea sediment, human and animal intestinal tracts, etc.) [17]. SRB are mostly classified in the class Deltaproteobacteria and differ from other classes in their characteristic type of metabolism [18]. SRB use sulfate reduction respiration to obtain necessary energy [19-22]. Another descriptive feature of SRB is their cellular shape. Their cells can be spherical, oval, spiral or vibroid [1,18]. The positive occurrence of SRB is characterized by a strong odor of hydrogen sulfide emission [23,24]. At the moment, the classification of sulfate-reducing microorganisms has been validly revised. However, according to Bergey's Manual of Determinative Bacteriology (1994), SRB were divided on the basis of $16 \mathrm{~S}$ rRNA into the following groups $[17,23,24]$ : 
- Gram-negative mesophilic SRB; these do not form spores and are one of the most widespread SRB in nature (genera Desulfovibrio, Desulfobotulus, Desulfobulbus, Desulfohalobium and Desulfomicrobium);

- Gram-positive spore-forming bacteria; these are a typical representative (genus Desulfotomaculum) that can be identified from soil samples (according to the updated classification, these microorganisms are represented and included in order Clostridiales);

- Gram-negative thermophilic sulfate-reducing microorganisms (genus Thermodesulfobacterium);

- Gram-negative thermophilic archaeal sulfate-reducing microorganisms; these include members of the genus Archaeoglobus that can only be found in anaerobic, underwater, hydrothermal environments because they require salt and high temperature for their growth.

The majority of these groups use sulfate as a terminal electron acceptor during anaerobic respiration. The presence of SRB with high metabolic activity can be identified by the blackening of water and sediments [23].

SRB are important hydrogen-utilizing organisms that, despite their occurrence in other ecosystems, colonize the digestive tract of mammals [11,25-29]. Previous studies have indicated that SRB play an important role in the development of intestinal bowel disease. SRB are also an important factor with regards to food biotechnology, and they can also play a role in part methylation of mercury. Certainly, the presence of different microorganisms in the gut, and the application of probiotics, can influence the eco-physiology of SRB in the intestinal environment [25]. Moreover, SRB have successfully adapted to almost all ecosystems on Earth [2].

\subsection{Water Environment}

SRB are often found in aquatic polluted environments [1,12]. Pollution can be of anthropogenic or of natural origin. The presence of sulfate can lead to a number of microbial processes and sulfide formation. Large microbial pollution due to the growth of SRB was recorded in canals and ports such as Venice or the city of Bruges in Belgium. SRB can also be found in the aqueous phases of oil and gasoline storage tanks [12].

In marine waters, SRB can be found more in the upper layers of sediment, where low redox conditions are encountered. Their known competitors, methanogenic archaea, are commonly found in the lower parts of sediment [30]. When SRB and methanogenic archaea occur together in marine sediments, they do not compete against each other, but rather complement each other in the degradation of organic matter. For instance, in marine sediment, SRB and methanogenic archaea are often present together, but methanogens degrade non-competitive substrates and produce methane [25]. Samples of Desulfovibrio spp., Desulfotalea and Desulfuromonas have been found in the upper part of the marine sediment $(100 \mathrm{~cm})[1,31]$. At the same time, Desulfosporosinus and Desulfovibrio have been most often isolated from the deeper layers. However, a study conducted by Barton \& Hamilton (2007) [1] reported that the amount of SRB was low in comparison to the total microbial population inhabiting saltwater environments. It was confirmed that SRB from deep-sea habitats are much more barotolerant than species from near-surface environments [1].

A relatively high population density of SRB has been observed in wastewater biofilms. The composition of the microbial community in wastewater depends on the ability of the organisms to adhere to the surface of the biofilm [32]. Six major genera of SRB have been found in wastewater biofilms: Desulfomicrobium, Desulfovibrio, Desulfonema, Desulforegula, Desulfobacterium, and Desulfobulbus [1]. The authors found that Desulfobulbus spp. generated the highest population density of about $10^{8}-10^{9}$ cells per $\mathrm{cm}^{-3}$ from SRB [32]. High sulfur reduction was found in a narrow anaerobic zone, which was located 150-300 $\mu \mathrm{m}$ below the biofilm surface. As a result, the biofilm formed in the wastewater facilitated the growth of anaerobic SRB under aerobic conditions [32]. 


\subsection{Surfaces of Corrosive Metals}

The colonization of surfaces by SRB is one of the issues of the oil and gas industry, as hydrogen sulfide produced by SRB can cause corrosion and contamination of hydrocarbon products [33]. Corrosion of iron and ferrous alloys occurs not only in aquatic but also in terrestrial environments, regardless of nutrient content, temperature, pressure and $\mathrm{pH}$ [1]. Microbial corrosion (MIC) is a biological process that damages the surfaces of corrosive materials due to the action of not only SRB, but also other microorganisms such as aerobic and autotrophic bacteria [24,34]. A scheme of iron metal corrosion by SRB is shown in Figure 2.

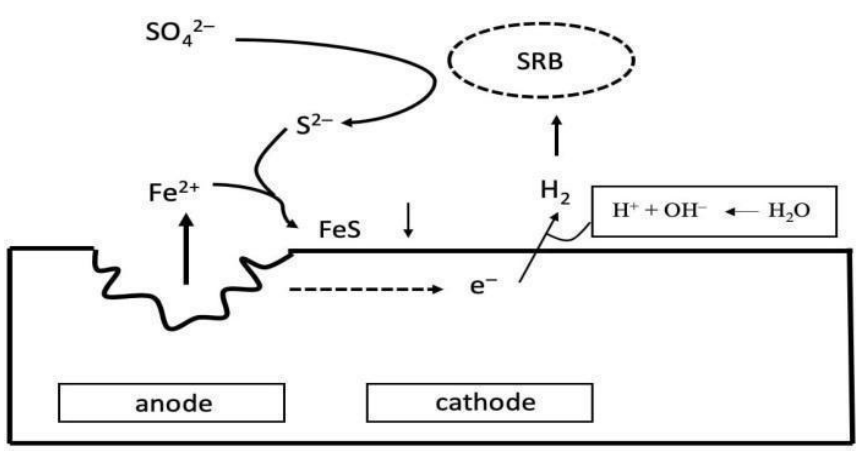

Figure 2. Scheme of iron metal corrosion by SRB (modified from Barton and Fauque, 2009 [2]).

SRB consume $\mathrm{H}_{2}$, and as a result, depolarize the cathode. When $\mathrm{Fe}^{2+}$ is released from the anode, a depression is formed in the metal and insoluble $\mathrm{FeS}$ is created. $\mathrm{H}^{+}$from ionizing water is combined with electrons to form $\mathrm{H}_{2}$ for SRB [2].

\subsection{Corrosion of Concrete, Stone Elements and Masonry}

Concrete pipes can also be subject to microbial corrosion [2]. The main cause of corrosion of concrete pipes is the metabolic process of SRB. Bacteria grow in water sediment at the bottom of the pipes and hydrogen sulfide is formed there. Once the hydrogen sulfide is produced by SRB, an aerobic zone occurs, and the sulfate-oxidizing bacteria begin to form sulfuric acid, which gradually dissolves the stone surfaces [32,34].

MIC is the result of a chemical interaction between a metal material and the environment in which the metal is located [2]. The result is a loss of material. Most often, it is an electrochemical process in which electrons from a metal are transported through several redox reactions to a final electron acceptor that is close to the metal surface [32]. There are several mechanisms by which SRB affect corrosion [2], including biofilm formation and attachment on the anode side. In this process, a set of natural bacteria, including SRB, accumulates on the metal surface; it is assumed that the effect of the so-called "quorum sensing" tunes the oxidation, localizes the bacteria on the metal material and creates a depression in this place [2]. Another mechanism by which SRB accelerate corrosion is depolarization at the cathode, which occurs because SRB consume $\mathrm{H}_{2}$ facilitated by hydrogenases. Corrosion can be prevented by the use of protective materials [34]. Plastic pipes with an uneven inner surface or pipes that are highly alkaline on their walls [2].

\subsection{Gastrointestinal Tract}

The large intestine is a complex microbial ecosystem inhabited by a number of different microbial species [1]. The abundance and composition of organisms plays an important role in human metabolism, and also in the health, disease or physiology of the human body. There are about $10^{11}-10^{12}$ microbial cells in $1 \mathrm{~g}$ of intestinal contents. 143 stool samples were examined for the abundance of SRB, and it was found that $83 \%$ of the specimens contained SRB at a concentration of $10^{2}-10^{11}$ per $1 \mathrm{~g}$ of feces [35]. It was also shown that the incidence of SRB influence the number of methanogenic archaea [36,37]. It is well-known that SRB and methanogenic archaea compete for nutrients in the gastrointestinal tract (GIT). 
A study revealed a negative correlation between the concentration of methane in the breath to the number of SRB in fecal samples [36].

In the intestinal microbial composition, hydrogen-utilizing microorganisms play an important role in the metabolism of molecular hydrogen $\left(\mathrm{H}_{2}\right)$ and sulfur [19]. Due to the fact that SRB use $\mathrm{H}_{2}$ as an electron donor, they facilitate fermentation processes $[38,39]$.

Anaerobic bacteria represent an integral component of the human microbiome. While many of them are associated with maintaining optimal health, others are involved in a variety of pathological processes, both in immune-competent and immunocompromised individuals [40-42]. The most common SRB species that occur in humans and animals are: Desulfovibrio (64-81\%), Desulfobacter (9-16\%), Desulfobulbus (5-8\%), Desulfomonas (3-10\%) and Desulfotomaculum (2\%). The genus Desulfovibrio is the most common genus of SRB [43,44]. Desulfovibrio is the most isolated genus of SRB and is found in samples in which inflammatory bowel disease has been confirmed [4,5,45-47]. Desulfotomaculum ruminis and D. acetoxidans originate from intestines [12].

SRB most commonly occur along with Actinobacteria, Firmicutes, and Proteobacteria [11]. $\mathrm{SRB}$ significantly affect the $\mathrm{pH}$ in the gastrointestinal tract, since they form hydrogen sulfide and acetic acid, and these substances lower $\mathrm{pH}$ [5]. The growth conditions of intestinal SRB in the GIT are greatly influenced by the concentration of sulfates, which varies among individuals. However, this depends on the type of diet [48].

\section{Conditions Determining the Viability of Sulfate-Reducing Bacteria}

Representatives of SRB occur at all sites that meet anaerobic conditions [12]. SRB are able to tolerate temperatures from $-5^{\circ} \mathrm{C}$ to $75^{\circ} \mathrm{C}$. They are able to tolerate a large $\mathrm{pH}$ range (5-9.5) and a large osmotic pressure range [1,12].

The presence of sulfate and lactate in the human gut contributes significantly to the growth support of SRB $[4,8]$. This is also related to the subsequent accumulation of their metabolites, acetate and hydrogen sulfide, in the gastrointestinal environment. In a mixed culture, the growth of SRB was supported by increased sulfur availability [1]. Sulfated polysaccharides, such as mucin and chondroitin sulfate, could be used by SRB as electron acceptors. It has also been shown that when sulfate concentrations increased, the growth of Desulfovibrio desulfuricans also increased [44].

\subsection{Physical Conditions}

Temperature. SRB strains, which are classified as mesophilic, are known to have a temperature optimum of about $30^{\circ} \mathrm{C}$, but can also tolerate up to $45-48^{\circ} \mathrm{C}$ [12]. However, such a large temperature range is more connected with environmental SRB [12,49]. Intestinal SRB species are grown at $37^{\circ} \mathrm{C}$. This temperature corresponds to warm-blooded animals and humans. Most thermophilic SRB were found in geothermal environments and in oil field waters [23]. The optimum growth temperature of thermophilic SRB (Thermodesulfobacterium) is from $54^{\circ} \mathrm{C}$ to $70{ }^{\circ} \mathrm{C}$, and the maximum temperature at which the bacteria are still able to grow is $85^{\circ} \mathrm{C}$ [1].

$\mathrm{pH}$. As mentioned above, SRB are able to tolerate a range of $\mathrm{pH}$ from 5 to 9.5 , but this depends on the environment from which they originally isolated [12]. Although the $\mathrm{pH}$ level in the large intestine of humans or animals is limited and depends on a number of different factors (composition and enzymatic activity of intestinal microorganisms, digestion process and consumed food), the $\mathrm{pH}$ in the human digestive tract is most often reported to be around 7.6 to 8 . However, the $\mathrm{pH}$ in the colon is at least one unit lower and lies between 5.7 in the caecum and 6.7 in the rectum [50]. The $\mathrm{pH}$ measured in feces is 7 [51]. Microbial growth is said to reach a maximum when the medium has a $\mathrm{pH}$ between 7 to 8 [5]. When the medium reached a $\mathrm{pH}$ of less than 6, a $26 \%$ decrease in microbial growth was recorded when compared to the medium at a $\mathrm{pH}$ of 7 to 8 [49]. It was concluded that adults and elderly people (64 to 83 years) supported a higher number of SRB than young people aged around 15 to 20 years [52]. 


\subsection{Competition and Coexistence with Other Intestinal Microorganisms}

Coexistence between hydrogenotrophic microbes (SRB and methanogenic archaea) and hydrogenogenic microbes (Clostridium, Bacteroides and Escherichia) is essential to maintain fermentative processes in the gut [11]. Desulfovibrio, which uses $\mathrm{H}_{2}$ produced by Clostridium and Bacteroides, can serve as an example [27]. Methanobrevibacter competes with Desulfovibrio for $\mathrm{H}_{2}$. The inhibition of SRB by methanogenic archaea (increased methanogenesis) results in the accumulation of short chain fatty acids with succinate and lactate [37]. A concentration of $200 \mathrm{mg} \mathrm{L}^{-1}$ of hydrogen sulfide is regarded as an upper limit and can cause inhibition of methanogenesis [53]. The increased availability of sulfate in the gut can lead to the inhibition of methanogenesis [37].

When sulfate is present in the large intestine, the occurrence of SRB is promoted [54]. However, when sulfate levels are reduced, methanogenic archaea predominate in the large intestine that can strongly compete with SRB for the availability of important metabolites of the intestinal microbiota $[11,54]$. Sulfate present in the digestive tract can come from both exogenous and endogenous environments [55]. Exogenous sources most often include drinking water and diet. Specific sulfate concentrations have been measured in more than 200 commonly available foods and beverages [48]. Foods high in sulfate ( $>10 \mu \mathrm{mol} \mathrm{g}^{-1}$ or up to $1 \mathrm{mg} \mathrm{g}^{-1}$ ) include certain types of bread, soy flour, dried fruit and sausages. Beverages which commonly contain sulfates $\left(>2.5 \mu \mathrm{mol} \mathrm{mL} \mathrm{m}^{-1}\right.$ or $\left.0.25 \mathrm{mg} \mathrm{mL}^{-1}\right)$ include some beers, ciders and wines. About $95 \%$ of the sulfate is absorbed in the gastrointestinal tract, and the remaining $5 \%$ can be found in the feces. Sources of sulfates of endogenous origin include sulfate mucins, sulfate-conjugated bile, and also, for example, chondroitin sulfate [55]. Sulfate ions in organic compounds need to lose the sulfate group, and in that case, sulfate becomes available. Sulfate does not only serve to support SRB growth and suppress growth of methanogenic archaea, but during sulfate dissimilation reduction, sulfate is used as the final electron acceptor [56-59].

If sulfate is present, Desulfovibrio and Desulfobulbus intestinal species are able to use $\mathrm{H}_{2}$ in the intestinal environment. The coexistence of SRB and methanogenic archaea found in the same ecosystem is possible if both groups of microorganisms use different electron donors [23]. Lactate is one of the main electron donors that occurs within the large intestine [49]. Lactate can be produced by lactic acid-producing bacteria such as Lactobacillus, Streptococcus, Bifidobacterium and others. Lactic acid as a final product of metabolism is then used by SRB [46].

\subsection{Biochemical Characteristics of Sulfate-Reducing Bacteria}

For intestinal bacteria, polysaccharides, starch and cellulose serve as the main sources of energy and carbon [1,12]. They can also use a certain amount of oligosaccharides and proteins. The main products of intestinal metabolism are acetate, short chain fatty acids, propionate, butyrate, $\mathrm{H}_{2}$ and $\mathrm{CO}_{2}$. The most common electron donors of SRB are $\mathrm{H}_{2}$, lactate and acetate [11,12]. Frequent removal of $\mathrm{H}_{2}$ from the lumen by SRB is essential for maintaining a healthy gut [11]. In contrast, sulfate or sulfite serve as electron acceptors (similar to thiosulfate and sulfur, in some cases) for the formation of hydrogen sulfide. Other possible electron donors for SRB growth are fatty acids, glutamate, serine, alanine, ethanol, and a variety of other organic acids such as succinate and pyruvate [36]. The most frequently used electron donors of intestinal SRB are lactate, pyruvate, acetate and ethanol (Figure 3). 


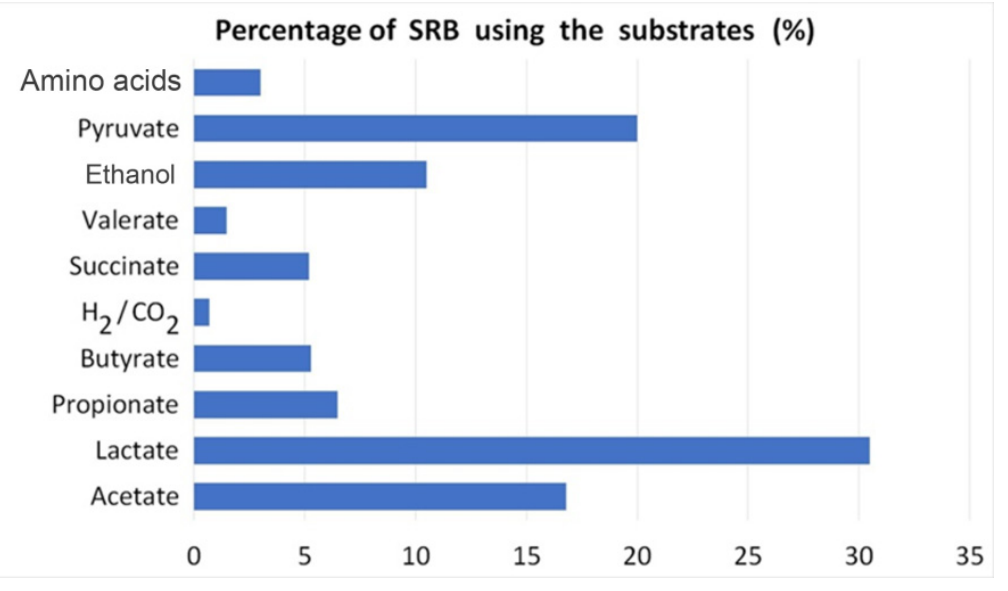

Figure 3. Different types of electron donors used by intestinal SRB which were isolated from human fecal samples (data from Gibson et al., 1988 [36]).

Gibson et al., 1988, found that SRB differ with regards to their substrate utilization sprectrum; Desulfovibrio spp. use lactate and $\mathrm{H}_{2}$, Desulfobacter spp. utilize acetate, Desulfobulbus spp. use propionate and $\mathrm{H}_{2}$, Desulfomonas spp. utilize lactate, and lastly, acetate and butyrate are used by Desulfotomaculum spp. [37].

Inhibitors. It is clear that, for SRB, one of the main inhibitors is molecular oxygen $\left(\mathrm{O}_{2}\right)[12,24]$. However, it is mentioned that SRB are capable of some adaptation to the environment where $\mathrm{O}_{2}$ is present [60]. For example, SRB colonizing a drinking water biofilm have been able to survive up to $72 \mathrm{~h}$ of exposure to aeration. Of the SRB, the genus Desulfovibrio is the most tolerant to an environment with a certain amount of $\mathrm{O}_{2}$ [61].

High concentrations of various metals are reported to be inhibitors of SRB growth. The toxicity of individual metals depends on the experimental conditions (amount of inoculum, number of cells, $\mathrm{pH}$, temperature). Molybdates have been found to inhibit SRB growth by inhibiting sulfate reduction, thereby reducing the possibility of sulfate transport into the bacterial cell and, thus, reducing possible energy production [33].

The following organisms were used to test the degree of toxicity of molybdates: Desulfotomaculum ruminis, Desulfovibrio vulgaris, and Desulfovibrio desulfuricans (two species). Postgate $\mathrm{C}$ medium was used in the experiment. Bacterial growth in the medium was inhibited at a concentration ranging from $40-200 \mu \mathrm{mol} \mathrm{L}^{-1}$ of the molybdate. Simultaneously, selenium inhibition of SRB growth was tested. Selenium inhibited SRB growth at a concentration between 160 and $320 \mu \mathrm{mol} \mathrm{L}^{-1}$. The presence of $50 \mu \mathrm{mol} \mathrm{L}^{-1}$ thiosulfate completely suppressed the effect of selenium. A comparison of the effect of selenium and molybdates shows that molybdates have more mechanisms of inhibition than selenium, since the addition of thiosulfate to the molybdate resulted in only partial inhibition [33].

Hydrogen sulfide. Hydrogen sulfide formation is dependent on SRB growth, which is strongly influenced by environmental $\mathrm{pH}[45,46,62-64]$. This compound is highly toxic. If hydrogen sulfide is not effectively removed from the gut, its accumulation can lead to damage of the colon's epithelial cells. It has been reported that increased levels of hydrogen sulfide in the gut may be associated with inflammatory bowel disease [44,55]. Hydrogen sulfide can be removed in the gut by detoxification with the help of intestinal epithelial cells or, due to ongoing bacterial growth, can be incorporated into cellular material $[37,44]$. The accumulation of hydrogen sulfide in the intestinal environment can be the result of sulfate metabolism inhibition in mammals and increased SRB activity [45]. Hydrogen sulfide toxicity can even cause DNA damage [62], leading to the formation of an unstable genome, the accumulation of mutations and, in extreme cases, the outbreak of colorectal cancer [65].

The extent that hydrogen sulfide influences the human gut is still not fully understood $[44,55]$. Further knowledge of this could be useful particularly in the medical sector, as hydrogen sulfide production can lead to inflammatory bowel diseases $[46,47]$. The 
construction industry is likewise affected by SRB. Here, SRB are responsible for corroding various surfaces, and thereby the structural integrity of these materials is weakened. It is therefore desirable to find suitable protection to combat these issues [2]. Furthermore, SRB are involved in water pollution [12]. Water pollution caused by SRB occurs mostly in canals.

\section{Cultivation and Storage of Sulfate-Reducing Bacteria}

The cultivation conditions for SRB differ depending on the isolation spot and their specific growth rate [3]. Generally, 1-5 days of cultivation under anaerobic conditions are reported. SRB derived from the environment possess lower specific growth rates than SRB that have been isolated from animals and humans. Some studies have described the differences in the growth of mesophilic and thermophilic SRB [12]. The growth of mesophilic $\mathrm{SRB}$ is usually very slow (from a few days to 2 weeks) at $30^{\circ} \mathrm{C}$, and at the same time, they require more anaerobic conditions than most other anaerobic microorganisms [58]. Thermophilic SRB grow much faster (12-18 h) at $55^{\circ} \mathrm{C}$ [12].

Beerens and Romond (1977) [51] isolated SRB in tubes containing liquid Postgate medium [12]. The bacterial suspension was transferred to the medium in test tubes, and $2 \mathrm{~mL}$ of paraffin was pipetted over the upper surface to maintain anaerobic conditions. The bacteria could then be cultured up to $37^{\circ} \mathrm{C}$ in the thermostat for 7 days. Then, it was possible to observe an increase in bacteria, which was manifested by blackening of the medium, mainly at the bottom of the tubes and slightly along their walls [51].

Some intestinal SRB are very difficult to cultivate or yet uncultivable [49], such as, for example, the family Desulfovibrionaceae. Due to the fact that SRB occur together with other microorganisms, such as Bacteroides, Pseudomonas, and Clostridium, they are demanding not only for the mentioned cultivation, but mainly for the necessary isolation of a pure SRB culture [3]. Postgate media and other media that exist are created primarily for species of the genus Desulfovibrio which are native to the natural environment [12].

\subsection{Isolation of Intestinal Sulfate-Reducing Bacteria}

The following procedure can be utilized for the isolation of intestinal SRB: samples should be cultured in sterilized Eppendorf tubes, completely filled with liquid medium and incubated at $37^{\circ} \mathrm{C}$ [49]. To detect the presence of SRB, it is necessary to add Mohr's salt to the sterilized medium [3]. Mohr's salt $\left[\left(\mathrm{NH}_{4}\right)_{2} \mathrm{Fe}\left(\mathrm{SO}_{4}\right)_{2} \cdot 6 \mathrm{H}_{2} \mathrm{O}\right]$ readily dissociates into free $\mathrm{Fe}^{2+}$ ions that interact with hydrogen sulfide. 10\% Mohr's salt solution and 1\% $\mathrm{Na}_{2} \mathrm{~S} \cdot 9 \mathrm{H}_{2} \mathrm{O}$ solution, which must be anaerobically prepared to avoid oxidation of $\mathrm{S}^{2-}$, must be autoclaved separately [63]. Then, both solutions may be added to the sterile medium. After adding the Mohr's salt solution and 20-30 $\mu \mathrm{L}$ of $\mathrm{Na}_{2} \mathrm{~S} \cdot 9 \mathrm{H}_{2} \mathrm{O}$ solution to the medium, a black circle forms in the medium, which confirms the interaction of hydrogen sulfide and the free $\mathrm{Fe}^{2+}$ complex released from the Mohr's salt. The observable black coloration of the medium is the result of a growing SRB culture due to the FeS complex. SRB require an $\mathrm{O}_{2-}$ free environment for growth [1,12]. The establishment of an ideal anoxygenic environment can be achieved in two ways:

1. The entire tube or Eppendorf is filled to the brim with Postgate medium;

2. One $\mathrm{mL}$ of sterile liquid paraffin is added dropwise to the surface of the medium, thus keeping anaerobic conditions.

It was also reported that the addition of a $3 \%$ solution of $\mathrm{Na}_{2} \mathrm{SO}_{3} \cdot 7 \mathrm{H}_{2} \mathrm{O}$ to the medium inhibits other bacteria $[3,49]$.

\subsection{Media for Cultivation of Sulfate-Reducing Bacteria}

Postgate medium B is reported as a basic medium for the detection and cultivation of Desulfovibrio and Desulfotomaculum; the $\mathrm{pH}$ of this medium should be between 7.0-7.5 [12]. Postgate medium $\mathrm{C}$ is a clear medium for biomass production of the genus Desulfovibrio at pH 7.5 (Table 1). Postgate medium E is used for the isolation of "pure" cultures of 
SRB with the recommended $\mathrm{pH}$ of 7.6 and also serves for the census of grown bacterial populations [12].

Table 1. Composition of different cultivation media.

\begin{tabular}{ccccc}
\hline Salts $\left(\mathbf{g ~ L}^{-1}\right)$ & Postgate B & Postgate C & Postgate E & $\begin{array}{c}\text { Modified by Kovac \& } \\
\text { Kushkevych, 2017 [49] }\end{array}$ \\
\hline $\mathrm{Na}_{2} \mathrm{SO}_{4}$ & - & 4.5 & 1 & 3 \\
\hline $\mathrm{KH}_{2} \mathrm{PO}_{4}$ & 0.5 & 0.5 & 0.5 & 0.3 \\
\hline $\mathrm{K}_{2} \mathrm{HPO}_{4}$ & - & - & - & 0.5 \\
\hline $\mathrm{NH}_{4} \mathrm{Cl}$ & 1 & 1 & 1 & 1 \\
\hline $\mathrm{CaCl}_{2} \cdot 6 \mathrm{H}_{2} \mathrm{O}$ & - & 0.06 & 1 & 0.06 \\
\hline $\mathrm{Yeast} \mathrm{extract}^{-1}$ & 1 & 1 & 1 & 0.1 \\
\hline $\mathrm{MgSO}_{4} \cdot 7 \mathrm{H}_{2} \mathrm{O}$ & 2 & 0.06 & 2 & - \\
\hline $\mathrm{CaSO}_{4}$ & 1 & - & - & 0.1 \\
\hline Ascorbic acid & 0.1 & - & 0.1 & - \\
\hline $\begin{array}{c}\text { Thioglycolic } \\
\text { acid }\end{array}$ & 0.1 & - & - & 0.2 \\
\hline$(\mathrm{NH} 4)_{2} \mathrm{SO}_{4}$ & - & - & - & \\
\hline
\end{tabular}

\section{Preservation of Intestinal Microorganisms}

One of the main reasons for the development of preservation methods of intestinal microorganisms is the possible production of therapeutic microbiota [66], such as fecal transplants and probiotics [67]. The microbiome is a unique natural resource that has possible medical applications. The result of the currently occurring human way of life entails the extinction of microbial species due to exposure to adverse environmental conditions such as diet, antibiotic use or stress [67-70]. Therefore, it is important to find suitable methods for preserving the intestinal microbiome to allow the timely restoration of the intestinal microflora with minimal safety risks. The best methods for long-term storage of microorganisms are cryopreservation and lyophilization $[13,14]$.

Lyophilization, also known as freeze-drying under vacuum, is a method in which the sample is first frozen. The amount of solvent (usually water) is then reduced to a level where biological activities or chemical reactions are no longer promoted. The amount is reduced first by sublimation and then by desorption (as a secondary drying process). However, one of the disadvantages of lyophilization is that it has a low percentage of microorganisms that survive storage at very low temperatures [16]. Mutations, membrane damage, protein denaturation, and water crystallization are also frequently observed in this method $[16,71]$.

\subsection{Cryopreservation of Intestinal Microorganisms}

This is one of the methods for long-term storage of cultures [72]. Cryopreservation is a process in which viable microbes are preserved by cooling to temperatures below $0{ }^{\circ} \mathrm{C}$ [13]. It is the only method that is widely applicable and has been proven to be reliable for the preservation of microorganisms. However, it is necessary that the cryopreservation be tuned for each individual type of microorganism [73]. At such low temperatures, all biological activities, including biochemical processes, are suspended (anabiosis) [74]. When temperatures drop $0{ }^{\circ} \mathrm{C}$, water becomes inaccessible, and thus, dehydrated cells, which have no further access to water, can be stored at temperatures below $0{ }^{\circ} \mathrm{C}$ [72].

The following procedure is used for the cryopreservation of Escherichia coli 451-B [75,76]. Some of the most important conditions of the medium, which serves to restore the growth of the microorganisms after cryopreservation, are osmolarity and pH level [13]. Most cryoprotectants are toxic to cells at normal temperatures. Therefore, it is desirable to 
remove cryoprotectants from the medium after thawing (by centrifugation) or to reduce their concentrations (by dilution).

\subsection{Methods of Cryopreservation}

Long-term storage methods are still being developed and tested [13]. It is found that the temperature is not sufficient for the long-term storage of living microorganisms, while the use of extreme freezing boxes and boxes with solid carbon dioxide is much more advantageous (Figure 4). In general, temperatures above $-30^{\circ} \mathrm{C}$ usually give poor results due to a number of side effects [72].

The five most common methods of cryopreservation:

\begin{tabular}{|l|l|} 
1. Laboratory freezing boxes & $-20^{\circ} \mathrm{C}$ to $-30{ }^{\circ} \mathrm{C}$ \\
2. Extreme freezers & $-60^{\circ} \mathrm{C}$ to $-80^{\circ} \mathrm{C}$ \\
3. Boxes with solid carbon dioxide & "dry ice", $-78{ }^{\circ} \mathrm{C}$ \\
\hline 5. Dewar vessel with liquid nitrogen & $-140{ }^{\circ} \mathrm{C}$ to $-150^{\circ} \mathrm{C}$ \\
\hline
\end{tabular}

Figure 4. The five most common cryopreservation methods and the stated ideal temperatures inside the boxes in ${ }^{\circ} \mathrm{C}$; data from Hubálek, 1996 [13].

Liquid nitrogen $\left(-196^{\circ} \mathrm{C}\right)$ is currently the most widely used liquefied gas used in cryopreservation due to low consumption and its safety in handling [13].

\subsection{Laboratory Equipment, Instruments and Materials}

Microorganisms are stored using various laboratory equipment. In cryopreservation, it depends on the material from which the ampoules or vials are made [15]. Glass or plastic ampoules are commonly used. These materials differ in their behavior in heat or cold conduction during cryopreservation and subsequent thawing. In polypropylene bottles, the conduction of heat or cold is slower than in glass ampoules.

Glass ampoules/vials. Borosilicate glass ampoules are commonly used in liquid nitrogen storage $[77,78]$. Glass ampoules must be sealed to prevent probable suspension leakage or liquid nitrogen contamination. After immersion in liquid nitrogen, the liquid from the LN can penetrate a incompletely closed ampoule. This ampoule then has a high probability of exploding due to the rapid expansion of nitrogen gas. It is therefore necessary to carry out a pre-freeze inspection.

Another vessel can be glass ampoules with a screw cap $(10.30 \mathrm{~mm})$ and a capacity of $2 \mathrm{~mL}[78,79]$. These vessels have been successfully used in the cryopreservation of strictly anaerobic phototrophic bacteria. These ampoules contained $\mathrm{O}_{2}$-impermeable butyl rubber stoppers and plastic autoclavable screw caps that allow the samples to be inoculated directly into the center of the hole. Storage in ampoules with screw caps was not only sufficient, but also safe, advantageous and sufficient to create an anaerobic environment without the need for an anaerobic chamber [80]. This method is therefore time-saving and relatively inexpensive. Thanks to these advantages, it could be used in small laboratories or large culture collections.

Plastic bottles. Plastic cryovials are safer and much better to handle than glass ampoules [13]. Therefore, glass vials are being replaced by plastic ones. Polypropylene cryogenic vials ( $47.12 \mathrm{~mm}, 2 \mathrm{~mL}$ volume) with screw caps and silicone seals are often used. Polypropylene and polycarbonate $(1-5 \mathrm{~mL})$ cryovials are excellent for storing samples in liquid nitrogen vapors (around -130 to $-170{ }^{\circ} \mathrm{C}$ ) and in conventional refrigerated boxes, 
but are less useful for direct loading. Indeed, liquid nitrogen can penetrate vials during storage in the same manner as immersing glass vials in liquid nitrogen [15,81-84]. A possible solution is to immerse the cryovial in liquid nitrogen only for a short time ( $<30 \mathrm{~min})$, in order to achieve the effect of deep freezing.

The use of plastic bottles is advantageous as they are more durable in comparison to glass bottles and the risk of an explosive reaction is eliminated. It is less problematic if some liquid nitrogen enters the vials and the surrounding liquid nitrogen becomes contaminated with non-pathogenic organisms than if unsterilized liquid nitrogen were to contaminate a partially closed vial. As a result, special polypropylene resealable packaging for cryovials is available. Although these packages prevent the penetration of liquid nitrogen into ampoules and vials, they take up more space in freezer containers.

Pasteur pipettes. As a possible alternative to plastic cryovials, disposable plastic Pasteur pipettes (Figure 5) are also available [82]. The Figure 5 shows a sealed Pasteur pipette "head" labeled with a felt-tip pen (A), a sealed Paster pipette "head" labeled with a ballpoint pen (B), an aluminum stand for holding pipettes during cryopreservation (C), part of the pipette after separation of the tip from the rest of the pipette and subsequent sealing of the end with a $2 \mathrm{~mL}$ volume of liquid (D), and an unmodified pipette (E). These plastic pipettes are made of polyethylene and have a $4 \mathrm{~mL}$ capacity with dimensions of $4.2 \cdot 1.4 \mathrm{~cm}$ and a tip length of about $11 \mathrm{~cm}$.

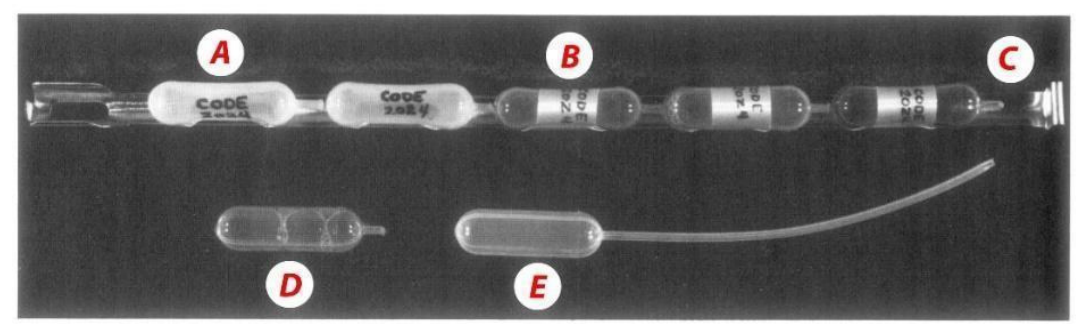

Figure 5. Plastic (polyethylene) Pasteur pipette used for freezing. Taken from the Walter Reed Army Institute of Research; by Jackson et al., 1981 [82].

Prior to cryopreservation itself, a portion of the tip needs to be separated from the pipette head in which the cell suspension will be stored. The place where the tip separated from the rest of the pipette must be heat sealed. The advantage is that there is no significant heating of the suspension during sealing. After sealing, it is beneficial to verify whether the complete healing of the material has been achieved and there is no leakage of the heterogeneous mixture. If the suspension drips, this can be corrected by resealing [82]. Another advantage is, of course, the cheaper price of pasteurized pipettes compared to plastic cryovials. Working with pipettes and filling their contents with the examined sample is much easier than with plastic or glass ampoules. The author confirms that during the cryopreservation of more than 200 sealed pipettes in LN for one year, no contamination with liquid nitrogen occurred. However, if a frozen pipette is dropped or otherwise mishandled, it may break.

\subsection{Cryoprotectants}

Different types and combinations of cryoprotectants are an integral part of cryopreservation methods and can highly influence the results of cryopreservation. Their task is to protect cells from possible damage that can be caused by osmotic stress due to the presence of external ice and from the dangerous formation of internal ice crystals [16]. A large number of different mixtures of cryoprotectants can protect microorganisms from drying out and radiation, and can protect proteins from thermal damage $[13,85]$.

The most common cryoprotectants are solutions with glycerol, sucrose, ethylenediaminetetraacetic acid (EDTA) and dimethylsulfoxide (DMSO). Other cryoprotectants are trehalose, methanol, glucose, 1,2-propanediol, proline, glycine, fructose, galactose and lac- 
tose. The most commonly used ingredients are glycerol and DMSO [84]. It is recommended that they be tested at a concentration of $10 \%(v / v)$ before use [84].

When using permeable cryoprotectants, proper equilibration must not be ignored [86]. In cases such as glycerol or DMSO, it is recommended to allow the cell suspension to equilibrate for a period of time with a certain temperature before the freezing process takes place. For glycerol, the time is $30-60 \mathrm{~min}$ at ambient temperature. For DMSO, it is advisable to leave the suspension for $15-30 \mathrm{~min}$ at $4{ }^{\circ} \mathrm{C}$. This is because DMSO takes about 15-30 min for the cryoprotectant to penetrate the cell wall and the cell membrane and balance the intracellular solutions before the cell suspension can be frozen. For slow cryoprotectants such as glycerol, they need more than $30 \mathrm{~min}$ for this process. Semipermeable cryoprotectants penetrate only through the cell wall, not through the cell membrane. Examples are monosaccharides, amino acid disaccharides and other low molecular weight polymers. In some methanogenic archaea, betaine, $\alpha$-glutamate, the beta-amino acids $\beta$-glutamine as well as $\mathrm{N}-\varepsilon$-acetyl- $\beta$-lysine have been described to act as osmoprotective substances. Some of these osmoprotective compounds might also be considered cryoprotective compounds [87]. Recently, a novel cryoprotectant, carboxylated poly-L-lysine, was examined and found to indicate restricted mobility and increased solution viscosity of eukaryotic cells. In addition, intermolecular interactions facilitated the glass transition of carboxylated poly-L-lysine, which prevents intracellular ice formation and osmotic shock during freezing [88].

High molecular weight polymer cryoprotectants, such as proteins, polysaccharides, and others, are impermeable and only protect the cell from the formation of external ice, and this process does not require equilibration time. However, the possible use of a combination of penetrating and non-penetrating cryoprotectants may be advantageous due to differences in the cell wall structure of individual intestinal microorganisms [66]. The temperature at which the state of the suspension equalizes depends mainly on the degree of toxicity of the cryoprotectant used [85]. An example is DMSO, which is less toxic at $0-5{ }^{\circ} \mathrm{C}$ than at higher temperatures. However, the absence of toxic effects is not necessarily an indicator of a good cryoprotectant [84].

Glycerol is sterilized by autoclaving at $121^{\circ} \mathrm{C}$ for $15 \mathrm{~min}$ [13]. When bacterial cells are placed in liquid nitrogen, glycerol prevents the internal formation of crystals that form at high low temperatures [89].

One of the most common methods of cryopreserving anaerobic bacteria fecal specimens (Bifidobacterium, Enterobacter, Enterococcus, and Lactobacillus) is using glycerol as a cryoprotectant [84]. The authors compared the number of bacteria before and after freezing. There were $10.3 \log \left(\mathrm{CFU} \mathrm{g}{ }^{-1}\right)$ anaerobes before the freezing process and a decrease of $\approx 0.05 \%$ after freezing. Bifidobacterium formed the dominant part of the anaerobic sample in the intestinal microflora. Before freezing, $9.7 \log \left(\mathrm{CFU} \mathrm{g}{ }^{-1}\right)$ was present; however, after cryopreservation a significant decrease $\left(9.0 \log \left(\mathrm{CFU} \mathrm{g}^{-1}\right)\right.$ was recorded. Enterococcus, the sample of which was less than $8 \operatorname{logs}\left(\mathrm{CGU} \mathrm{g}^{-1}\right)$ before storage, was not significantly altered by cryopreservation. Enterobacterium behaved similarly to Enterococcus; thus, no significant decrease was observed [90].

To study the effect of glycerol as a cryoprotectant for the protection of E. coli, two different concentrations were used [76,91]. The 3\% glycerol concentration resulted in a complete protection, whereas the $1 \%$ concentration had only partial protection. A comparison was still made if no amount of glycerol, i.e., no cryoprotectant, was used. The $3 \%$ glycerol concentration resulted in an approximately $95 \%$ survival rate. However, it was demonstrated that the rate of freezing influenced viability when using $1 \%$ glycerol concentration. Viability values ranged from $53 \%$ to approximately $86 \%$. Without the use of any cryoprotectant, viability decreased to $20 \%$ during freezing and was greatly affected by the cooling rate.

DMSO could be sterilized by filtration through glass filters [13]. DMSO bottles which have been open for an extended period of time should be avoided, as oxidation and degradation of products can arise as a result. DMSO is solid at $18^{\circ} \mathrm{C}$. 
Sugars: Sucrose. Sugars are another classic group of cryoprotectants used in cryopreservation [92]. Disaccharides such as maltose, sucrose and trehalose can protect the cell from freezing by causing it to shrink, thereby reducing the internal formation of ice crystals. It is necessary to use a $5 \%$ sucrose concentration when rapid freezing and cooling occurs to completely protect $E$. coli ( $>90 \%$ viability). As with glycerol, the authors performed an experiment with half the concentration (2.5\%) of sucrose. The test showed that a $5 \%$ concentration of sucrose almost completely protected E. coli. At $2.5 \%$ concentration, the cooling rate depended. If the cooling rate was below $5{ }^{\circ} \mathrm{C} \mathrm{min}-1$, the $2.5 \%$ sucrose concentration was almost as effective as $5 \%$. However, if the cooling rate was above $5{ }^{\circ} \mathrm{C} \min ^{-1}$, $2.5 \%$ gave only moderate protection [92].

Tween 80. In Lactobacillus bulgaricus, the positive effect of the addition of classical cryoprotectants (10\% glycerol, DMSO, combinations thereof etc.) on viability was not known [93]. Therefore, it was proposed to observe changes in viability that occurred after the addition of polysorbate 80 (Tween 80) to the medium in different genera of Lactobacillus bulgaricus. Tween 80 is a surfactant that should protect the cell surface [75]. After the addition of Tween 80 to the strain L. bulgaricus NCS4, the strain appeared to be the most stable (Table 2) [93]. The increase in bacterial growth after the addition of Tween 80 was not as significant in NCS2 and NCS3 as in the strain NCS1. However, L. bulgaricus of the strain NCS1 did not have complete protection against damage.

Table 2. Addition of Tween 80 to the medium and its effect on viability (data from Smittle et al., 1972) [93].

\begin{tabular}{cccc}
\hline $\begin{array}{c}\text { Lactobacillus } \\
\text { bulgaricus }\end{array}$ & Medium & Death (\%) & $\begin{array}{c}\text { Loss of Acid } \\
\text { Production (\%) }\end{array}$ \\
\hline \multirow{2}{*}{ L. bulgaricus NCS1 } & $-\mathrm{T} 80$ & 67 & 5 \\
\cline { 2 - 4 } & $+\mathrm{T} 80$ & 3 & 1 \\
\hline \multirow{2}{*}{ L. bulgaricus NCS2 } & $-\mathrm{T} 80$ & 83 & 32 \\
\cline { 2 - 4 } & $+\mathrm{T} 80$ & 38 & 9 \\
\hline \multirow{2}{*}{ L. bulgaricus NCS3 } & $-\mathrm{T} 80$ & 65 & 70 \\
\cline { 2 - 4 } & $+\mathrm{T} 80$ & 49 & 40 \\
\hline \multirow{2}{*}{ L. bulgaricus NCS4 } & $-\mathrm{T} 80$ & 7 & 7 \\
\cline { 2 - 4 } & $+\mathrm{T} 80$ & 0 & 5 \\
\hline
\end{tabular}

Tween 80 was used also to store E. coli [75]. The protective effect of Tween 80 was related to the cooling rate of the suspension. Viability was observed at $1 \%$ and $0.5 \%$ Tween 80 concentrations. The results show that at $1 \%$ concentration, the viability of $E$. coli was highest when the cooling rate was above $10{ }^{\circ} \mathrm{C} \mathrm{min}-1$. When the cooling rate was reduced below $10{ }^{\circ} \mathrm{C} \mathrm{min}^{-1}$, the protective effect of Tween 80 decreased rapidly. Even at a cooling rate of $1{ }^{\circ} \mathrm{C} \mathrm{min}-1$, Tween 80 was slightly toxic. $0.5 \%$ of the Tween 80 concentration was toxic even at a cooling rate of $10^{\circ} \mathrm{C} \mathrm{min}^{-1}$. In summary, Tween 80 is a good cryoprotectant for rapid cooling.

Synergistic effect of cryoprotectants. Some cryoprotectants are good to combine because they can act well or even better on the cell together than if they were to produce an effect on their own $[85,94]$. The synergistic effect can thus increase the protection of microorganisms during freezing. However, it is not necessary to combine only cryoprotectants with each other. They can also interact with key cell molecules. One component may have a higher effect than the other; however, when added together the results are beneficial to cryopreservation processes [94].

Effect of glycerol and Tween 80 in E. coli. Cryopreservation of E. coli has been reported to result most commonly in cell membrane and cell wall damage [91]. Glycerol is said to be able, under certain conditions, to protect the membrane and the wall from possible damage. However, Tween 80 fails to protect the cell wall. Tween 80 is only able to prevent 
membrane damage. Tween 80 also protects against the possible entry of certain substances into the cell. Examples of these substances might include sucrose and glucose-6-phosphate dehydrogenase. Tween 80 thus plays a significant role in promoting viability [91].

\subsection{Viability}

Effective storage of cells facilitates preservation or restoration to the initial state in which the cells were prior to freezing. These states may include morphology, metabolism, capsule formation, mucus production, adhesion, gene expression, and overall changes in genetic material, as well as any other alterations that could occur during cryopreservation [16].

Cell size is also related to the quality of preservation [72]. A smaller cell size gives higher viability values after cryopreservation than larger cells. Viability is usually measured by CFU counting [63]. Thus, it is the number of cells that survived the storage process at very low temperatures. In this method, Petri dishes with bacteria are cultured in a thermostat at a temperature that corresponds to the growth conditions of the microorganism. To determine viability, the dishes are then compared with experimental and control microorganisms. One of the other methods for determining the preservation quality of microorganisms, or viability, is based on the ability to form colonies or coatings [95]. Another aspect that influences viability is the rate or degree of cooling of a given sample of microorganisms [73]. In some microorganisms, several days to 4 weeks of pre-cultivation and adaptation to low temperatures (around $5{ }^{\circ} \mathrm{C}$ ) can have a positive effect on cryopreservation [13]. This adaptation allows the cell to alter their proteome and membrane composition [96].

Differences in viability within the same genus. When cryopreserving different species of the same genus with liquid nitrogen under comparable circumstances and typical conditions, different results may occur [13]. An example is the bacterium Lactobacillus bulgaricus, which is classified as a microorganism that is used as a probiotic and is often used in dairy products [93]. During cryopreservation (at $-196{ }^{\circ} \mathrm{C}$ ), it was evident that within the number of colonies and lactic acid production, viability varied from species to species. L. bulgaricus NCS1 was sensitive to freezing, while NCS4 displayed a tolerance to freezing, and therefore, zero deaths were recorded (Table 3).

Table 3. Stability of individual species of L. bulgaricus during cryopreservation in liquid nitrogen (data from Smittle et al., 1972 [93]).

\begin{tabular}{lcccc}
\hline & \multicolumn{4}{c}{ Storage Time } \\
\cline { 2 - 5 } $\begin{array}{c}\text { Lactobacillus } \\
\text { bulgaricus }\end{array}$ & \multicolumn{2}{c}{ 1. Day } & 2. Day \\
\cline { 2 - 5 } & Death (\%) & $\begin{array}{c}\text { Loss of Acid } \\
\text { Production (\%) }\end{array}$ & Death (\%) & $\begin{array}{c}\text { Loss of Acid } \\
\text { Production (\%) }\end{array}$ \\
\hline L. bulgaricus NCS1 & 95 & 73 & 99 & 69 \\
L. bulgaricus NCS3 & 54 & 31 & 72 & 32 \\
L. bulgaricus NCS4 & 0 & 8 & 0 & 8 \\
\hline
\end{tabular}

Influence of cell membranes. One of the other variants of good cryoresistance may be the variability or fluidity of cell membranes (cytoplasmic and mitochondrial membranes) [13]. The organization and overall stability of membranes is determined by the strength of the interactions between its individual components [97]. The interactions are sensitive to temperature, $\mathrm{pH}$, ionic strength and the volume of surrounding water. Membrane variability and the strength of interactions are determined by the composition of membrane sterols and phospholipids and especially by the composition of unsaturated fatty acids. The smaller the amount of unsaturated aliphatic acids, the less fluid or variable (more rigid) the membranes are and the lower their cryoresistance [97].

Concentration, age and physiological state of microorganisms. The age and physiological state of microorganisms are considered to be the main factors determining the ability to survive stress [95]. It is generally accepted that cryopreservation of microbial cultures in the stationary phase has a higher resistance than in the exponential growth phase [95,98]. Péter 
\& Reichart (2001) measured the percentage of survival at different stages of growth after the freezing and subsequent thawing process of Lactobacillus plantarum and E. coli [98]. The survival rate of L. plantarum rate was $78.9 \%$ and $89.7 \%$ from the exponential and stationary growth phase, respectively. Moreover, E. coli exhibited a survival rate of $47.4 \%$ and $54.7 \%$ from the exponential and stationary phase, respectively. In addition, it was observed that higher concentrations of $E$. coli frozen at a temperature of about $-30^{\circ} \mathrm{C}$ resulted in a higher survival rate after cryopreservation than when a lower concentration of cells had been frozen [99]. The following formula is used to calculate the percentage of recovered E. coli cells:

$$
R=\frac{78.97-12.4 \cdot 10^{10}}{x}
$$

$R$ is the percentage of recovered cells; $x$ is a number of $E$. coli cells in $1 \mathrm{~mL}$ of distilled water before freezing; 78.97 is a coefficient; $12.4 \cdot 10^{10}$ is a constant number of cells that always die during cryopreservation despite the initial concentration of cells.

It should be noted that the coefficient of survival remains constant. A high proportion of the cells in suspension concentrate around the ice crystals during the freezing process. It is also noteworthy to mention that cells can directly disperse into ice crystals. A higher cooling rate may give a higher probability that the cells will be dispersed inside ice crystals. The probability that the cells will be inside the ice crystals may decrease if freezing is done very slowly [99].

Polysaccharides and proteins. Calcott \& MacLeod (1974) [76] mention that there is an association between the amount of protein and the possible increase in survival after the freezing process in E. coli. The authors report that increased cryotolerance is demonstrated in species with lower protein content. It has also been found that storage substances such as glycogen or polyglucose, which are stored inside the E. coli cell, have protected the cell from the strong temperature changes that can occur during cryopreservation $[75,76]$.

\subsubsection{Stress Factors}

During long-term storage at deep low temperatures, a large number of stress factors act on the cell. Grout et al., (1990) [16] found that the rate of cooling significantly affects the survival of individual cells. If the cooling rate is too fast, intracellular ice crystals form. During slow cooling, the fatal damage is related to the external hypertonic effect of the solution. Freezing and thawing causes high stress for all cells [16]. Therefore, emphasis is given to the procedures, methods and substances used, which determine the extent to which the organism is still able to respond to stress factors to which it is exposed during the entire cryopreservation process. It controls how the cell and cytoplasm respond to cooling, heating and overall changes in the chemical environment. The main factors influencing the viability of samples during freezing are: exposure to low temperatures, the mechanical and physical action of ice crystals, changes in the external and internal character of the environment in solution, damage to membrane structures (especially impacts on semipermeability), cytoplasmic accumulation and shrinkage of cytoskeletal structures [16]. Cryopreserved microorganisms can be divided according to the phase of damage during the process of cryopreservation and subsequent thawing into five categories [13]:

- Cooling to temperatures above $0{ }^{\circ} \mathrm{C}$ (cold shock);

- Further gradual cooling below $0{ }^{\circ} \mathrm{C}$ (frost damage);

- $\quad$ Storage temperature;

- Heating to room temperature (defrost damage);

- Recovery.

Related to this is Mazur's best-known "two-factor" hypothesis, which suggests that upon slow cooling, ice crystals form extracellularly, and cells are damaged due to exposure to concentrated solutions. However, upon rapid cooling, cells are destroyed by the formation of ice crystals directly within the cells [100-102].

The cellular response to freezing is schematically shown in Figure 6. During slow cooling (A), the cell is able to maintain osmotic balance by the outflow of water; the cell 
shrinks and only external ice crystals are formed. In the second case, with optimal cooling (B), the cell is unable to release water fast enough and thus maintain the osmotic balance; therefore, there is only a small amount of shrinkage of the cell and the cell contains a few ice crystals. During rapid cooling $(C)$, the cell does not lose any water. Due to this effect, within the cell, small ice crystals develop.

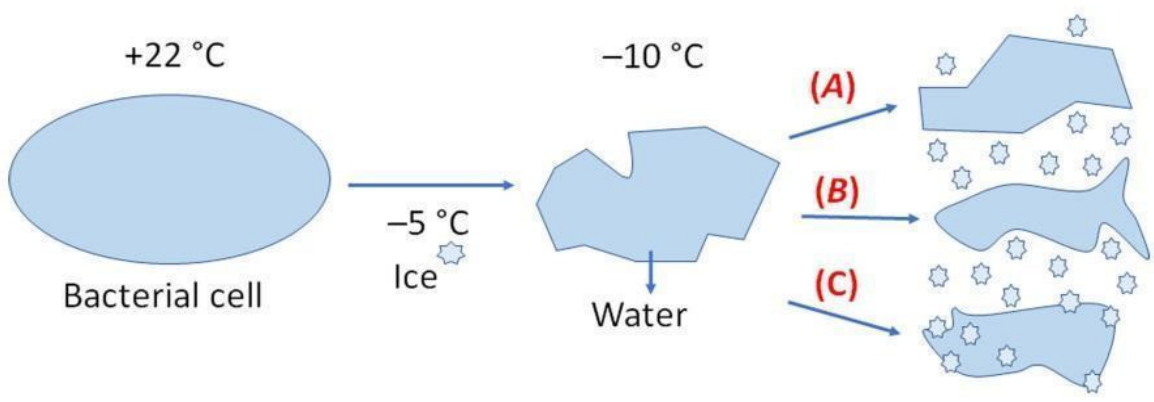

Figure 6. Schematic representation of the cellular response to freezing: (A) slow cooling, (B) optimal cooling, and (C) very fast cooling; data from Gao \& Critser, 2000 [100].

Salinity and Temperature. Storing microorganisms in distilled water leads to a higher viability compared to cryopreservation in physiological $\mathrm{NaCl}$ solution [75]. This was examined using E. coli 451-B [76]. The organism was frozen in either distilled water or $0.85 \% \mathrm{NaCl}$ solution. Moreover, ultra-fast freezing to $-196{ }^{\circ} \mathrm{C}$ followed by slow or rapid heating, or slow cooling to $-22{ }^{\circ} \mathrm{C}$ and slow heating or rapid heating were examined. The viability of $E$. coli was up to $78 \%$ when distilled water and ultra-fast cooling and rapid thawing were used. Using the same freezing and thawing procedure but using $\mathrm{NaCl}$ solution resulted in $12 \%$ viability. In contrast, viability decreased to $48 \%$ with slow cooling to $-22{ }^{\circ} \mathrm{C}$ in distilled water and rapid heating, while viability was $41 \%$ when using $\mathrm{NaCl}$ solution [75].

Damage to the cell membrane and cell wall. During cryopreservation and subsequent thawing of microorganisms in saline conditions, it was observed that both the cell wall and the cell membrane were damaged [75,76]. Membrane damage leads to increased permeability to small molecules and atoms such as potassium, nucleotides, amino acids. Moreover, sucrose can enter the cell in the same way as water [91].

Oxidative stress. Another important stress factor in strictly anaerobic intestinal microorganisms is oxidative stress [66]. The $\mathrm{O}_{2}$ tolerance ability varies from species to species. For example, Bacteroides thetaiotamicron is able to create a protective mechanism against $\mathrm{O}_{2}$ by scavenging enzymes that prevent the rapid formation of reactive $\mathrm{O}_{2}$ and perform remediation upon exposure to $\mathrm{O}_{2}[103,104]$. By adding riboflavin, cysteine and $\mathrm{HCl}$ in the preparation of the buffer, an environment can be created that protects the bacteria from possible contact with $\mathrm{O}_{2}$ during cryopreservation [105]. However, highly susceptible strictly anaerobic bacteria may still require a completely $\mathrm{O}_{2}$-free environment.

\subsubsection{Osmoregulation and Osmotic Stress}

Osmoregulation. Osmoregulation might indicate cryoresistance in microorganisms [13]. Therefore, it is important to determine the optimal cooling rate in order to maintain osmoregulation during cooling.

Osmotic stress. It is suggested to prevent the osmotic stress of microorganisms that occurs during the recovery process after thawing by using hypertonic solutions $(1.75 \% \mathrm{NaCl}$, $7.5 \%$ glycerol or sorbitol) [13]. It has also been suggested that osmotolerance may be strain specific [106,107]. The main consequence of freezing is the exclusion of various molecules from the crystal lattice and their accumulation in the residual external liquid [16,73]. Thus, a hypertonic environment is created around the cell. As cooling continues, osmotic stress begins to act on the unfrozen cell. The cell responds to osmotic stress by losing water and the cell thus becomes dehydrated. If the cell drains the water faster than the heat, the later 
it will decrease with decreasing temperature. The water in the external environment will freeze and the osmotic stress of the environment will increase. The lower the ambient temperature, the higher the concentration of the unfrozen solution and the higher the leakage of water from the cytoplasm [73].

\section{Summary of the Obtained Information with the Possibility of Application to SRB}

Studies concerning the long-term storage of SRB in the form of cryopreservation are uncommon. Because SRB are able to corrode iron and, after a long time, stainless steel, it was initially recommended that glassware be used for longer-term storage [12]. However, this has been refuted in the cryopreservation of intestinal bacteria, and the use of plastic ampoules or vials has been recommended [15,81-84]. A possible alternative to preserve SRB may be the use of screw-capped glass ampoules $[79,80]$, with which the maintenance of anaerobic conditions was successfully performed and had a number of advantages.

The use of silicone or thin rubber or rubber handles in SRB storage has been shown to be permeable to $\mathrm{O}_{2}$ [12]. The air that penetrates inside the container in which the SRB are stored can impair their growth. Hence, thick rubber or polyvinyl chloride plugs, tubes or other connections may be used. The establishment of anoxygenic conditions during long-term storage could also be performed using paraffin [51]. SRB differ from each other not only within individual genera, but also in terms of species within one genus. The genus Desulfovibrio is considered to be quite resistant to the presence of $\mathrm{O}_{2}$ and is generally much easier to isolate and cultivate than most other SRB genera [108].

Comparing Desulfovibrio desulfuricans ssp. desulfuricans to Desulfovibrio acrylicus, the optimal $\mathrm{pH}$ of $D$. acrylicus is 7.4 , while the optimal $\mathrm{pH} D$. desulfuricans ssp. desulfuricans is 7.2 to 7.8 . The optimal growth temperature is almost identical: $30-37^{\circ} \mathrm{C}$ for D. acrylicus and $30-36{ }^{\circ} \mathrm{C}$ for $D$. desulfuricans ssp. desulfuricans. However, the optimal $\mathrm{NaCl}$ concentration is 0-1 $\mathrm{g} \mathrm{L}^{-1}$ for D. desulfuricans ssp. desulfuricans and $18 \mathrm{~g} \mathrm{~L}^{-1}$ for D. acrylicus $[12,59,108,109]$.

SRB can be found in fresh and salt waters $[12,110]$. Growth of SRB was observed at $1 \% \mathrm{NaCl}$ concentration, but when $\mathrm{NaCl}$ concentration was 3\%, no growth was observed. This reaction to the saline environment has also been reported in E. coli [75]. Storage of intestinal microorganisms in distilled water led to a higher viability than when performing cryopreservation in $\mathrm{NaCl}$ solution, depending on the freezing/thawing method that had been applied. Regarding the freezing process of SRB, it has been mentioned that it is best to use glycerol (10\%) as a cryoprotectant [12]. Long-term freezing is possible to store SRB at $-80{ }^{\circ} \mathrm{C}$ or in liquid nitrogen [108]. For shorter storage in the range of $4-6$ weeks, SRBs can be stored at $4-6^{\circ} \mathrm{C}$.

\section{Conclusions}

The aim of this review was to describe the distribution of SRB in various environments, the methods of cryopreservation of intestinal bacteria, and to compare whether the information is applicable for the cryopreservation of SRB. According to the obtained information, it is recommended that SRB are stored in glass vials to prevent corrosion. The storage should be performed in distilled water or in a solution with a low salt concentration. However, differences in viability among the species of the same SRB genus might be observed. According to the present studies and literature information, an unambiguous description of SRB cryopreservation would need more extensive laboratory research. Certainly, vast phylogenetic diversity influences the processes of method development of cryopreservation of SRBs. In particular, the molecular interactions between the cell, the cryoprotective compound and freezing mediator molecules might be worth considering. Moreover, standardization of the methods and determination of the optimal protectant for cryopreservation of SRB for the purpose of later medical and biotechnological applications would be desirable, since no universal method is known and method standardization would certainly have economic impacts in different industries.

Author Contributions: Conceptualization, A.K. and I.K.; writing—original draft preparation, A.K., I.K., D.D. and S.K.-M.R.R.; writing—review and editing, A.K., D.D., J.G., P.K. and S.K.-M.R.R.; 
visualization, A.K.; supervision, I.K. and M.V.; project administration, I.K. and M.V.; funding acquisition, M.V., P.K. and S.K.-M.R.R. All authors have read and agreed to the published version of the manuscript.

Funding: This study was supported by Grant Agency of the Masaryk University (MUNI/A/1425/2020). Open access funding was provided by the University of Vienna.

Institutional Review Board Statement: Not applicable.

Informed Consent Statement: Not applicable.

Data Availability Statement: Not applicable.

Acknowledgments: This study was supported by the Grant Agency of the Masaryk University (MUNI/A/1425/2020).

Conflicts of Interest: The authors declare no conflict of interest.

\section{References}

1. Cambridge University Press. Sulphate-Reducing Bacteria: Environmental and Engineered Systems; Barton, L., Hamilton, W.A., Eds.; Cambridge University Press: Cambridge, NY, USA, 2007; ISBN 978-0-521-85485-6.

2. Barton, L.L.; Fauque, G.D. Chapter 2 Biochemistry, Physiology and Biotechnology of Sulfate-Reducing Bacteria. In Advances in Applied Microbiology; Elsevier: Amsterdam, The Netherlands, 2009; Volume 68, pp. 41-98. ISBN 978-0-12-374803-4.

3. Kushkevych, I. Isolation and Purification of Sulfate-Reducing Bacteria. In Microorganisms; Blumenberg, M., Shaaban, M., Elgaml, A., Eds.; IntechOpen: London, UK, 2020; ISBN 978-1-83880-187-8.

4. Kushkevych, I.; Dordević, D.; Kollár, P. Analysis of Physiological Parameters of Desulfovibrio Strains from Individuals with Colitis. Open Life Sci. 2019, 13, 481-488. [CrossRef] [PubMed]

5. Kushkevych, I.; Dordević, D.; Vítězová, M. Analysis of PH Dose-Dependent Growth of Sulfate-Reducing Bacteria. Open Med. 2019, 14, 66-74. [CrossRef] [PubMed]

6. Kushkevych, I.; Kollar, P.; Suchy, P.; Parak, T.; Pauk, K.; Imramovsky, A. Activity of Selected Salicylamides against Intestinal Sulfate-Reducing Bacteria. Neuro Endocrinol. Lett. 2015, 36 (Suppl. 1), 106-113.

7. Kushkevych, I.V. Kinetic Properties of Pyruvate Ferredoxin Oxidoreductase of Intestinal Sulfate-Reducing Bacteria Desulfovibrio Piger Vib-7 and Desulfomicrobium Sp. Rod-9. Pol. J. Microbiol. 2015, 64, 107-114. [CrossRef]

8. Kushkevych, I.; Fafula, R.; Parák, T.; Bartoš, M. Activity of $\mathrm{Na}^{+} / \mathrm{K}^{+}$-Activated $\mathrm{Mg}^{2+}$-Dependent ATP-Hydrolase in the Cell-Free Extracts of the Sulfate-Reducing Bacteria Desulfovibrio Piger Vib-7 and Desulfomicrobium Sp. Rod-9. Acta Vet. Brno 2015, 84, 3-12. [CrossRef]

9. Kushkevych, I.V. Activity and Kinetic Properties of Phosphotransacetylase from Intestinal Sulfate-Reducing Bacteria. Acta Biochim. Pol. 2015, 62, 103-108. [CrossRef]

10. Kushkevych, I.; Coufalová, M.; Vítězová, M.; Rittmann, S.K.-M.R. Sulfate-Reducing Bacteria of the Oral Cavity and Their Relation with Periodontitis-Recent Advances. JCM 2020, 9, 2347. [CrossRef]

11. Ran, S.; Mu, C.; Zhu, W. Diversity and Community Pattern of Sulfate-Reducing Bacteria in Piglet Gut. J. Animal Sci. Biotechnol. 2019, 10, 40. [CrossRef]

12. Postgate, J. The Suphate-Reducing Bacteria, 2nd ed.; Cambridge University: Cambridge, NY, USA, 1984.

13. Hubálek, Z. Cryopreservation of Microorganisms at Ultra-Low Temperatures; Elsevier: Amsterdam, The Netherlands, 1996.

14. Trsic-Milanovic, N.; Kodzic, A.; Baras, J.; Dimitrijevic-Brankovic, S. The Influence of a Cryoprotective Medium Containing Glycerol on the Lyophilization of Lactic Acid Bacteria. J. Serb. Chem. Soc. 2001, 66, 435-441. [CrossRef]

15. Butterfield, W.; Jong, S.C.; Alexander, M.T. Polypropylene Vials for Preserving Fungi in Liquid Nitrogen. Mycologia 1978, 70, 1122-1124. [CrossRef]

16. Grout, B.; Morris, J.; Mclellan, M. Cryopreservation and the Maintenance of Cell Lines. Trends Biotechnol. 1990, 8, 293-297. [CrossRef]

17. Castro, H.F.; Williams, N.H.; Ogram, A. Phylogeny of Sulfate-Reducing Bacteria1. FEMS Microbiol. Ecol. 2000, 31, 1-9. [CrossRef]

18. Brenner, D.J.; Krieg, N.R.; Staley, J.T.; Garrity, G.M. The Proteobacteria, Part C: The Alpha-, Beta-, Delta-, and Epsilonproteobacteria. In Bergey's Manual of Systematic Bacteriology; Springer: Boston, MA, USA, 2005; p. 1388.

19. Kushkevych, I.; Vítězová, M.; Kos, J.; Kollár, P.; Jampílek, J. Effect of Selected 8-Hydroxyquinoline-2-Carboxanilides on Viability and Sulfate Metabolism of Desulfovibrio Piger. J. Appl. Biomed. 2018, 16, 241-246. [CrossRef]

20. Kushkevych, I.; Cejnar, J.; Treml, J.; Dordević, D.; Kollar, P.; Vítězová, M. Recent Advances in Metabolic Pathways of Sulfate Reduction in Intestinal Bacteria. Cells 2020, 9, 698. [CrossRef]

21. Kushkevych, I.; Kováč, J.; Vítězová, M.; Vítěz, T.; Bartoš, M. The Diversity of Sulfate-Reducing Bacteria in the Seven Bioreactors. Arch. Microbiol. 2018, 200, 945-950. [CrossRef] [PubMed]

22. Abdulina, D.; Kováč, J.; Iutynska, G.; Kushkevych, I. ATP Sulfurylase Activity of Sulfate-Reducing Bacteria from Various Ecotopes. Biotech 2020, 10, 55. [CrossRef] [PubMed] 
23. Fauque, G.D. Ecology of Sulfate-Reducing Bacteria. In Sulfate-Reducing Bacteria; Barton, L.L., Ed.; Springer: Boston, MA, USA, 1995; pp. 217-241. ISBN 978-1-4899-1584-9.

24. Hao, O.J.; Chen, J.M.; Huang, L.; Buglass, R.L. Sulfate-reducing Bacteria. Crit. Rev. Environ. Sci. Technol. 1996, 26, 155-187. [CrossRef]

25. Dordević, D.; Jančíková, S.; Vítězová, M.; Kushkevych, I. Hydrogen Sulfide Toxicity in the Gut Environment: Meta-Analysis of Sulfate-Reducing and Lactic Acid Bacteria in Inflammatory Processes. J. Adv. Res. 2020, 27, 55-69. [CrossRef]

26. Kushkevych, I.; Dordević, D.; Vítězová, M. Possible Synergy Effect of Hydrogen Sulfide and Acetate Produced by SulfateReducing Bacteria on Inflammatory Bowel Disease Development. J. Adv. Res. 2020, 21, 71-78. [CrossRef]

27. Černý, M.; Vítězová, M.; Vítěz, T.; Bartoš, M.; Kushkevych, I. Variation in the Distribution of Hydrogen Producers from the Clostridiales Order in Biogas Reactors Depending on Different Input Substrates. Energies 2018, 11, 3270. [CrossRef]

28. Kováč, J.; Vítězová, M.; Kushkevych, I. Metabolic Activity of Sulfate-Reducing Bacteria from Rodents with Colitis. Open Med. 2018, 13, 344-349. [CrossRef]

29. Kushkevych, I.; Vítězová, M.; Fedrová, P.; Vochyanová, Z.; Paráková, L.; Hošek, J. Kinetic Properties of Growth of Intestinal Sulphate-Reducing Bacteria Isolated from Healthy Mice and Mice with Ulcerative Colitis. Acta Vet. Brno 2017, 86, 405-411. [CrossRef]

30. Plugge, C.M.; Zhang, W.; Scholten, J.C.M.; Stams, A.J.M. Metabolic Flexibility of Sulfate-Reducing Bacteria. Front. Microbio. 2011, 2, 81. [CrossRef] [PubMed]

31. Köpke, B.; Wilms, R.; Engelen, B.; Cypionka, H.; Sass, H. Microbial Diversity in Coastal Subsurface Sediments: A Cultivation Approach Using Various Electron Acceptors and Substrate Gradients. AEM 2005, 71, 7819-7830. [CrossRef] [PubMed]

32. Okabe, S.; Itoh, T.; Satoh, H.; Watanabe, Y. Analyses of Spatial Distributions of Sulfate-Reducing Bacteria and Their Activity in Aerobic Wastewater Biofilms. Appl. Environ. Microbiol. 1999, 65, 5107-5116. [CrossRef]

33. Newport, P.J.; Nedwell, D.B. The Mechanisms of Inhibition of Desulfovibrio and Desulfotomaculum Species by Selenate and Molybdate. J. Appl. Bacteriol. 1988, 65, 419-423. [CrossRef]

34. Islander, R.L.; Devinny, J.S.; Mansfeld, F.; Postyn, A.; Shih, H. Microbial Ecology of Crown Corrosion in Sewers. J. Environ. Eng. 1991, 117, 751-770. [CrossRef]

35. Leclerc, H.; Oger, C.; Beerens, H.; Mossel, D.A.A. Occurrence of Sulphate Reducing Bacteria in the Human Intestinal Flora and in the Aquatic Environment. Water Res. 1980, 14, 253-256. [CrossRef]

36. Gibson, G.R.; Macfarlane, G.T.; Cummings, J.H. Occurrence of Sulphate-Reducing Bacteria in Human Faeces and the Relationship of Dissimilatory Sulphate Reduction to Methanogenesis in the Large Gut. J. Appl. Bacteriol. 1988, 65, 103-111. [CrossRef]

37. Gibson, G.R.; Macfarlane, S.; Macfarlane, G.T. Metabolic Interactions Involving Sulphate-Reducing and Methanogenic Bacteria in the Human Large Intestine. FEMS Microbiol. Ecol. 1993, 12, 117-125. [CrossRef]

38. Kushkevych, I.; Vítězová, M.; Vítěz, T.; Bartoš, M. Production of Biogas: Relationship between Methanogenic and SulfateReducing Microorganisms. Open Life Sci. 2017, 12, 82-91. [CrossRef]

39. Kushkevych, I.; Vítězová, M.; Vítěz, T.; Kováč, J.; Kaucká, P.; Jesionek, W.; Bartoš, M.; Barton, L. A New Combination of Substrates: Biogas Production and Diversity of the Methanogenic Microorganisms. Open Life Sci. 2018, 13, 119-128. [CrossRef] [PubMed]

40. Gajdács, M.; Spengler, G.; Urbán, E. Identification and Antimicrobial Susceptibility Testing of Anaerobic Bacteria: Rubik's Cube of Clinical Microbiology? Antibiotics 2017, 6, 25. [CrossRef] [PubMed]

41. Gajdács, M.; Urbán, E. Relevance of Anaerobic Bacteremia in Adult Patients: A Never-Ending Story? Eur. J. Microbiol. Immunol. 2020, 10, 64-75. [CrossRef] [PubMed]

42. Gajdács, M.; Ábrók, M.; Lázár, A.; Terhes, G.; Urbán, E. Anaerobic Blood Culture Positivity at a University Hospital in Hungary: A 5-Year Comparative Retrospective Study. Anaerobe 2020, 63, 102200. [CrossRef] [PubMed]

43. Gibson, G.R.; Macfarlane, G.T. Chemostat Enrichment of Sulphate-Reducing Bacteria from the Large Gut. Lett. Appl. Microbiol. 1988, 7, 127-133. [CrossRef]

44. Gibson, G.R.; Cummings, J.H.; Macfarlane, G.T. Growth and Activities of Sulphate-Reducing Bacteria in Gut Contents of Healthy Subjects and Patients with Ulcerative Colitis. FEMS Microbiol. Lett. 1991, 86, 103-112. [CrossRef]

45. Kushkevych, I.; Dordević, D.; Kollar, P.; Vítězová, M.; Drago, L. Hydrogen Sulfide as a Toxic Product in the Small-Large Intestine Axis and Its Role in IBD Development. JCM 2019, 8, 1054. [CrossRef]

46. Kushkevych, I.; Kotrsová, V.; Dordević, D.; Buňková, L.; Vítězová, M.; Amedei, A. Hydrogen Sulfide Effects on the Survival of Lactobacilli with Emphasis on the Development of Inflammatory Bowel Diseases. Biomolecules 2019, 9, 752. [CrossRef]

47. Kushkevych, I.; Castro Sangrador, J.; Dordević, D.; Rozehnalová, M.; Černý, M.; Fafula, R.; Vítězová, M.; Rittmann, S.K.-M.R. Evaluation of Physiological Parameters of Intestinal Sulfate-Reducing Bacteria Isolated from Patients Suffering from IBD and Healthy People. JCM 2020, 9, 1920. [CrossRef] [PubMed]

48. Florin, T.H.J.; Neale, G.; Goretski, S.; Cummings, J.H. The Sulfate Content of Foods and Beverages. J. Food Compos. Anal. 1993, 6, 140-151. [CrossRef]

49. Kováč, J.; Kushkevych, I. New Modification of Cultivation Medium for Isolation and Growth of Intestinal Sulfate-Reducing Bacteria. In Proceedings of the 24th International Ph.D. Students Conference, Brno, Czech Republic, 8-9 November 2017; Volume 2017, pp. 702-707.

50. Fallingborg, J.; Christensen, L.A.; Ingeman-Nielsen, M.; Jacobsen, B.A.; Abildgaard, K.; Rasmussen, H.H. PH-Profile and Regional Transit Times of the Normal Gut Measured by a Radiotelemetry Device. Aliment. Pharmacol. Ther. 2007, 3, 605-614. [CrossRef] 
51. Beerens, H.; Romond, C. Sulfate-Reducing Anaerobic Bacteria in Human Feces. Am. J. Clin. Nutr. 1977, 30, 1770-1776. [CrossRef]

52. Fite, A. Identification and Quantitation of Mucosal and Faecal Desulfovibrios Using Real Time Polymerase Chain Reaction. Gut 2004, 53, 523-529. [CrossRef]

53. Hilton, B.L.; Oleszkiewicz, J.A. Sulfide-Induced Inhibition of Anaerobic Digestion. J. Environ. Eng. 1988, 114, 1377-1391. [CrossRef]

54. Christl, S.U.; Gibson, G.R.; Cummings, J.H. Role of Dietary Sulphate in the Regulation of Methanogenesis in the Human Large Intestine. Gut 1992, 33, 1234-1238. [CrossRef] [PubMed]

55. Deplancke, B.; Hristova, K.R.; Oakley, H.A.; McCracken, V.J.; Aminov, R.; Mackie, R.I.; Gaskins, H.R. Molecular Ecological Analysis of the Succession and Diversity of Sulfate-Reducing Bacteria in the Mouse Gastrointestinal Tract. Appl. Environ. Microbiol. 2000, 66, 2166-2174. [CrossRef] [PubMed]

56. Kushkevych, I.; Dordević, D.; Vítězová, M.; Kollár, P. Cross-Correlation Analysis of the Desulfovibrio Growth Parameters of Intestinal Species Isolated from People with Colitis. Biologia 2018, 73, 1137-1143. [CrossRef]

57. Postgate, J.R. On the Nutrition of Desulphovibrio Desulphuricans. J. Gen. Microbiol. 1951, 5, 714-724. [CrossRef]

58. Postgate, J.R. Sulphate Reduction by Bacteria. Annu. Rev. Microbiol. 1959, 13, 505-520. [CrossRef]

59. Postgate, J.R.; Campbell, L.L. Classification of Desulfovibrio Species, the Nonsporulating Sulfate-Reducing Bacteria. Bacteriol. Rev. 1966, 30, 732-738. [CrossRef] [PubMed]

60. Bade, K.; Manz, W.; Szewzyk, U. Behavior of Sulfate Reducing Bacteria under Oligotrophic Conditions and Oxygen Stress in Particle-Free Systems Related to Drinking Water. FEMS Microbiol. Ecol. 2000, 32, 215-223. [CrossRef] [PubMed]

61. Krekeler, D.; Sigalevich, P.; Teske, A.; Cypionka, H.; Cohen, Y. A Sulfate-Reducing Bacterium from the Oxic Layer of a Microbial Mat from Solar Lake (Sinai), Desulfovibrio oxyclinae Sp. Nov. Arch. Microbiol. 1997, 167, 369-375. [CrossRef]

62. Attene-Ramos, M.S.; Wagner, E.D.; Plewa, M.J.; Gaskins, H.R. Evidence That Hydrogen Sulfide Is a Genotoxic Agent. Mol. Cancer Res. 2006, 4, 9-14. [CrossRef] [PubMed]

63. Kushkevych, I.; Leščanová, O.; Dordević, D.; Jančíková, S.; Hošek, J.; Vítězová, M.; Buňková, L.; Drago, L. The Sulfate-Reducing Microbial Communities and Meta-Analysis of Their Occurrence during Diseases of Small-Large Intestine Axis. JCM 2019, 8, 1656. [CrossRef]

64. Kushkevych, I.; Dordević, D.; Vítězová, M. Toxicity of Hydrogen Sulfide toward Sulfate-Reducing Bacteria Desulfovibrio Piger Vib-7. Arch. Microbiol. 2019, 201, 389-397. [CrossRef]

65. Pitcher, M.C.; Cummings, J.H. Hydrogen Sulphide: A Bacterial Toxin in Ulcerative Colitis? Gut 1996, 39, 1-4. [CrossRef]

66. Bircher, L.; Geirnaert, A.; Hammes, F.; Lacroix, C.; Schwab, C. Effect of Cryopreservation and Lyophilization on Viability and Growth of Strict Anaerobic Human Gut Microbes. Microb. Biotechnol. 2018, 11, 721-733. [CrossRef]

67. Smirnova, D.V.; Zalomova, L.V.; Zagainova, A.V.; Makarov, V.V.; Mezhevikina, L.M.; Fesenko, E.E.; Yudin, S.M. Cryopreservation of the Human Gut Microbiota: Current State and Perspectives. Int. J. Med. Microbiol. 2019, 309, 259-269. [CrossRef]

68. Bailey, M.T.; Dowd, S.E.; Galley, J.D.; Hufnagle, A.R.; Allen, R.G.; Lyte, M. Exposure to a Social Stressor Alters the Structure of the Intestinal Microbiota: Implications for Stressor-Induced Immunomodulation. Brain Behav. Immun. 2011, 25, 397-407. [CrossRef]

69. Blaser, M.J.; Falkow, S. What Are the Consequences of the Disappearing Human Microbiota? Nat. Rev. Microbiol. 2009, 7, 887-894. [CrossRef]

70. Jakobsson, H.E.; Jernberg, C.; Andersson, A.F.; Sjölund-Karlsson, M.; Jansson, J.K.; Engstrand, L. Short-Term Antibiotic Treatment Has Differing Long-Term Impacts on the Human Throat and Gut Microbiome. PLoS ONE 2010, 5, e9836. [CrossRef] [PubMed]

71. Giulio, B.D.; Orlando, P.; Barba, G.; Coppola, R.; Rosa, M.D.; Sada, A.; Prisco, P.P.D.; Nazzaro, F. Use of Alginate and CryoProtective Sugars to Improve the Viability of Lactic Acid Bacteria after Freezing and Freeze-Drying. World J. Microbiol. Biotechnol. 2005, 21, 739-746. [CrossRef]

72. Perry, S.F. Freeze-Drying and Cryopreservation of Bacteria. Mol. Biotechnol. 1998, 9, 59-64. [CrossRef] [PubMed]

73. Dumont, F.; Marechal, P.-A.; Gervais, P. Cell Size and Water Permeability as Determining Factors for Cell Viability after Freezing at Different Cooling Rates. Appl. Environ. Microbiol. 2004, 70, 268-272. [CrossRef] [PubMed]

74. Nova Biomedical. Cryopreservation: Technologies, Applications, and Risks/Outcomes; Colvert, A., Coty, H., Eds.; Cell biology research progress; Nova Biomedical: New York, NY, USA, 2013; ISBN 978-1-62618-475-6.

75. Calcott, P.H.; MacLeod, R.A. Survival of Escherichia Coli from Freeze-Thaw Damage: A Theoretical and Practical Study. Can. J. Microbiol. 1974, 20, 671-681. [CrossRef]

76. Calcott, P.H.; MacLeod, R.A. Survival of Escherichia Coli from Freeze-Thaw Damage: Influence of Nutritional Status and Growth Rate. Can. J. Microbiol. 1974, 20, 683-689. [CrossRef] [PubMed]

77. Butterfield, W.; Jong, S.C.; Alexander, M.T. Preservation of Living Fungi Pathogenic for Man and Animals. Can. J. Microbiol. 1974, 20, 1665-1673. [CrossRef]

78. Shannon, J.E.; Macy, M.L. Freezing, Storage, and Recovery of Cell Stocks. In Tissue Culture; Elsevier: Amsterdam, The Netherlands, 1973; pp. 712-718, ISBN 978-0-12-427150-0.

79. Malik, K.A. A New Method for Liquid Nitrogen Storage of Phototrophic Bacteria under Anaerobic Conditions. J. Microbiol. Methods 1984, 2, 41-47. [CrossRef]

80. Malik, K.A. Maintenance of phototrophic bacteria. In Maintenance of Microorganisms and Cultured Cells; The Department for Environment, Food and Rural Affairs: London, UK, 1991.

81. Hofmann, P. Cryopreservation of Fungi. World J. Microbiol. Biotechnol. 1991, 7, 92-94. [CrossRef] 
82. Jackson, P.R.; Jackson, J.E.; Raney, D.E. A Sterile Leakproof Plastic Vial for Cell Cryopreservation in Liquid Nitrogen: Application to Parasitic Protozoa. Cryobiology 1981, 18, 608-611. [CrossRef]

83. Simione, F.P.; Daggett, P.-M. Recovery of a Marine Dinoflagellate Following Controlled and Uncontrolled Freezing. Cryobiology 1977, 14, 362-366. [CrossRef]

84. Simione, F.P.; Daggett, P.-M.; McGrath, M.S.; Alexander, M.T. The Use of Plastic Ampoules for Freeze Preservation of Microorganisms. Cryobiology 1977, 14, 500-502. [CrossRef]

85. Hubálek, Z. Protectants Used in the Cryopreservation of Microorganisms. Cryobiology 2003, 46, 205-229. [CrossRef]

86. Heylen, K.; Hoefman, S.; Vekeman, B.; Peiren, J.; De Vos, P. Safeguarding Bacterial Resources Promotes Biotechnological Innovation. Appl. Microbiol. Biotechnol. 2012, 94, 565-574. [CrossRef] [PubMed]

87. Taubner, R.-S.; Schleper, C.; Firneis, M.; Rittmann, S. Assessing the Ecophysiology of Methanogens in the Context of Recent Astrobiological and Planetological Studies. Life 2015, 5, 1652-1686. [CrossRef] [PubMed]

88. Matsumura, K.; Hayashi, F.; Nagashima, T.; Rajan, R.; Hyon, S.-H. Molecular Mechanisms of Cell Cryopreservation with Polyampholytes Studied by Solid-State NMR. Commun. Mater. 2021, 2, 15. [CrossRef]

89. Fonseca, F.; Béal, C.; Corrieu, G. Operating Conditions That Affect the Resistance of Lactic Acid Bacteria to Freezing and Frozen Storage. Cryobiology 2001, 43, 189-198. [CrossRef] [PubMed]

90. Guérin-Danan, C. Storage of Intestinal Bacteria in Samples Frozen with Glycerol. Microb. Ecol. Health Dis. 1999, 11, 180-182. [CrossRef]

91. Calcott, P.H.; MacLeod, R.A. The survival of Escherichia coli from freeze-thaw damage: The relative importance of wall and membrane damage. Can. J. Microbiol. 1975, 21, 1960-1968. [CrossRef]

92. Fowler, A. Cryo-Injury and Biopreservation. Ann. N. Y. Acad. Sci. 2005, 1066, 119-135. [CrossRef]

93. Smittle, R.B.; Gilliland, S.E.; Speck, M.L. Death of Lactobacillus Bulgaricus Resulting from Liquid Nitrogen Freezing. Appl. Microbiol. 1972, 24, 551-554. [CrossRef]

94. Ruwart, M.J.; Holland, J.F.; Haug, A. Fluorimetric Evidence of Interactions Involving Cryoprotectants and Biomolecules. Cryobiology 1975, 12, 26-33. [CrossRef]

95. Heckly, R.J. Preservation of Microorganisms. In Advances in Applied Microbiology; Elsevier: Amsterdam, The Netherlands, 1978; Volume 24, pp. 1-53. ISBN 978-0-12-002624-1.

96. Streit, F.; Delettre, J.; Corrieu, G.; Béal, C. Acid Adaptation of Lactobacillus Delbrueckii Subsp. Bulgaricus Induces Physiological Responses at Membrane and Cytosolic Levels That Improves Cryotolerance. J. Appl. Microbiol. 2008, 105, 1071-1080. [CrossRef]

97. Williams, W.P.; Chapman, D.; Heber, U.; Franks, F.; Jaenicke, R. Cold-Induced Lipid Phase Transitions [and Discussion]. In Philosophical Transactions of the Royal Society of London B: Biological Sciences; The Royal Society Publishing: London, UK, 1990; Volume 326, pp. 555-570.

98. Péter, G.; Reichart, O. The Effect of Growth Phase, Cryoprotectants and Freezing Rates on the Survival of Selected Microorganisms during Freezing and Thawing. Acta Aliment. 2001, 30, 89-97. [CrossRef]

99. Tanno, K. An Explanation for the Cell Concentration Dependent Survival of Escherichia Coli after Freeze-Thawing. Ser. B Biol. Sci. 1979, 57-59.

100. Gao, D.; Critser, J.K. Mechanisms of Cryoinjury in Living Cells. ILAR J. 2000, 41, 187-196. [CrossRef] [PubMed]

101. Mazur, P.; Leibo, S.P.; Chu, E.H.Y. A Two-Factor Hypothesis of Freezing Injury. Exp. Cell Res. 1972, 71, 345-355. [CrossRef]

102. Mazur, P. The Role of Intracellular Freezing in the Death of Cells Cooled at Supraoptimal Rates. Cryobiology 1977, 14, 251-272. [CrossRef]

103. Mishra, S.; Imlay, J.A. An Anaerobic Bacterium, Bacteroides Thetaiotaomicron, Uses a Consortium of Enzymes to Scavenge Hydrogen Peroxide: $\mathrm{H}_{2} \mathrm{O}_{2}$ Scavenging Enzymes in Bacteroides Thetaiotaomicron. Mol. Microbiol. 2013, 90, 1356-1371. [CrossRef]

104. Pan, N.; Imlay, J.A. How Does Oxygen Inhibit Central Metabolism in the Obligate Anaerobe Bacteroides Thetaiotaomicron. Mol. Microbiol. 2001, 39, 1562-1571. [CrossRef] [PubMed]

105. Khan, M.T.; van Dijl, J.M.; Harmsen, H.J.M. Antioxidants Keep the Potentially Probiotic but Highly Oxygen-Sensitive Human Gut Bacterium Faecalibacterium Prausnitzii Alive at Ambient Air. PLoS ONE 2014, 9, e96097. [CrossRef]

106. Cebrián, G.; Arroyo, C.; Mañas, P.; Condón, S. Bacterial Maximum Non-Inhibitory and Minimum Inhibitory Concentrations of Different Water Activity Depressing Solutes. Int. J. Food Microbiol. 2014, 188, 67-74. [CrossRef] [PubMed]

107. Saegeman, V.S.M.; Ectors, N.L.; Lismont, D.; Verduyckt, B.; Verhaegen, J. Short- and Long-Term Bacterial Inhibiting Effect of High Concentrations of Glycerol Used in the Preservation of Skin Allografts. Burns 2008, 34, 205-211. [CrossRef]

108. Kuever, J. The Family Desulfovibrionaceae. In The Prokaryotes; Rosenberg, E., DeLong, E.F., Lory, S., Stackebrandt, E., Thompson, F., Eds.; Springer: Berlin/Heidelberg, Germany, 2014; pp. 107-133, ISBN 978-3-642-39043-2.

109. van der Maarel, M.J.E.C.; van Bergeijk, S.; van Werkhoven, A.F.; Laverman, A.M.; Meijer, W.G.; Stam, W.T.; Hansen, T.A. Cleavage of Dimethylsulfoniopropionate and Reduction of Acrylate by Desulfovibrio Acrylicus Sp. Nov. Arch. Microbiol. 1996, 166, 109-115. [CrossRef]

110. Kushkevych, I.; Abdulina, D.; Kováč, J.; Dordević, D.; Vítězová, M.; Iutynska, G.; Rittmann, S.K.-M.R. Adenosine-5'Phosphosulfate- and Sulfite Reductases Activities of Sulfate-Reducing Bacteria from Various Environments. Biomolecules 2020, 10, 921. [CrossRef] 